\title{
Atlantis
}

Critical Studies in Gender, Culture \& Social Justice

Études critiques sur le genre, la culture, et la justice

\section{The Impossibility of a Future in the Absence of a Past: Drifting in the In-Between}

\section{Sonja Boon et Kate Lahey}

Volume 40, numéro 1, fall 2019

URI : https://id.erudit.org/iderudit/1066419ar

DOI : https://doi.org/10.7202/1066419ar

Aller au sommaire du numéro

\section{Éditeur(s)}

Mount Saint Vincent University

ISSN

1715-0698 (numérique)

Découvrir la revue

Citer cet article

Boon, S. \& Lahey, K. (2019). The Impossibility of a Future in the Absence of a Past: Drifting in the In-Between. Atlantis, 40(1), 32-44.

https://doi.org/10.7202/1066419ar
Résumé de l'article

In this collaborative paper, we bring the work of Billy-Ray Belcourt, Leanne Betasamosake Simpson, Dionne Brand, and M. NourbeSe Philip into conversation in order to consider the concept of drift. Drawing on drift as both metaphor and methodology, we argue that drifting is not aimless or passive, as dictionary definitions suggest; rather, as a form of refusal, to follow the work of Eve Tuck and K. Wayne Yang (2014a, 2014b), it can be understood as resistance to colonial gestures of capture and containment. Inherently mobile, drift revels in inadvertent assemblages and volatile juxtapositions that reveal the artifice of the worlds we currently inhabit, in the process making new worlds possible. In this way, we suggest that drift is necessarily decolonial, in that it is premised on different ways of interacting among human, non-human, and more-than-human. Working through themes of intimacy, love, origins, dirt, and accountings, we argue that drift can be more productively read as an agential mode of kinning, making, and thinking together.
Ce document est protégé par la loi sur le droit d'auteur. L'utilisation des services d’Érudit (y compris la reproduction) est assujettie à sa politique d'utilisation que vous pouvez consulter en ligne.

https://apropos.erudit.org/fr/usagers/politique-dutilisation/ 


\section{The Impossibility of a Future in the Absence of a Past: Drifting in the In-Between}

Sonja Boon is Professor of Gender Studies, Memorial University, St. John's, Newfoundland and Labrador. An award-winning researcher, writer, and teacher, Sonja is interested in bodies, stories, identities, and theories, and has published on a variety of topics, from considerations of gender, class, embodiment, identity and citizenship in eighteenth-century medical letters, to breastfeeding selfies and virtual activism, vulnerability as longing in the writing of Hélène Cixous, auto/ethnography and the embodiment of maternal grief, and craftivism in the feminist classroom, among others. She is the author of two recent books: a critical memoir, What the Oceans Remember: Searching for Belonging and Home (WLU Press, 2019), and a collaborative book, Autoethnography and Feminist Theory at the Water's Edge: Unsettled Islands (with Lesley Butler and Daze Jefferies, Palgrave, 2018).

Kate Lahey is a PhD student at the Women \& Gender Studies Institute, University of Toronto. Kate's research focuses on intergenerational trauma, sexual violence, memory, secrets and material culture in outport Newfoundland. Her research explores how intergenerational trauma reverberates through our memories, dreams, bodies and family relations as paradoxical legacies of both silence and deep psychic knowing. Kate is a Newfoundlander, front woman of the band Weary, arts writer, board member of Girls Rock NL, and co-director of St. John's Womxn in Music.

Abstract: In this collaborative paper, we bring the work of Billy-Ray Belcourt, Leanne Betasamosake Simpson, Dionne Brand, and M. NourbeSe Philip into conversation in order to consider the concept of drift. Drawing on drift as both metaphor and methodology, we argue that drifting is not aimless or passive, as dictionary definitions suggest; rather, as a form of refusal, to follow the work of Eve Tuck and K. Wayne Yang (2014a, 2014b), it can be understood as resistance to colonial gestures of capture and containment. Inherently mobile, drift revels in inadvertent assemblages and volatile juxtapositions that reveal the artifice of the worlds we currently inhabit, in the process making new worlds possible. In this way, we suggest that drift is necessarily decolonial, in that it is premised on different ways of interacting among human, non-human, and more-than-human. Working through themes of intimacy, love, origins, dirt, and accountings, we argue that drift can be more productively read as an agential mode of kinning, making, and thinking together.

Keywords: drift, intimacy, decoloniality, kinning, refusal 
What might it mean to drift?

There is something ungraspable about drifting, something impossible. According to the Oxford English Dictionary Online, to drift is to meander, to go wherever the forces take you. It is to move without apparent intentionality, to be carried, swept, borne. In language, the dictionary tells us, to drift is to be rendered in passive voice.

To drift is to exist in a state of geographic, temporal, and psychic suspension, to exist in a state of timeand place-lessness; adrift, we are free of firm coordinates. Drifting, in this way, lacks direction; instead, drifters wander, destination uncertain. Drift, then, appears to lack agency; apparently purposeless, it aspires to aimlessness. To drift, it seems, is to leave the heavy lifting to others, to go with the flow. In this way, drift would appear to have no future; eternally unfinished, it is impossible, it cannot be realized. Nor, however, does drifting have a past: unmappable and endlessly mobile, drift lacks origins. Where, indeed, could drift begin?

In this collaborative paper, we offer an alternative reading of drift as a way towards understanding the impossibility of a future in the absence of a past, the unruliness of a geography that will not be fixed, and the complexities of a wounded world that cannot be mapped. Drawing on drift as both metaphor and methodology, we argue that drifting is not aimless or passive, as dictionary definitions suggest; rather, as a form of refusal, to follow the work of Eve Tuck and K. Wayne Yang (2014a, 2014b), it can be understood as resistance to colonial gestures of capture and containment. Taken literally, drift is about unsettling: to drift is to resist settling. Inherently mobile, drift revels in inadvertent assemblages and volatile juxtapositions that reveal the artifice of the worlds we currently inhabit, in the process making new worlds possible. In this way, we suggest that drift is necessarily decoloni$\mathrm{al}$, in that it is premised on different ways of interacting among human, non-human, and more-than-human. Working through themes of intimacy, love, origins, dirt, and accountings, we argue that drift can be more productively read as an agential mode of kinning, making, and thinking together.

Our theorizing here is informed by feminist, queer, Indigenous, and Black thought, and draws inspiration from the literary work of four Indigenous and Black writers and thinkers living and working in/on/with Turtle Island: Billy-Ray Belcourt, Leanne Betasamosake Simpson, M. NourbeSe Philip, and Dionne Brand. Belcourt's 2017 Griffin-prize-winning collection of poems, This Wound is a World, digs deep into the politics of grief, desire, trauma, sex, queerness, and indigeneity under, in, and beyond settler colonialism. Leanne Betasamosake Simpson's two books of short stories and songs, Islands of Decolonial Love and This Accident of Being Lost, explore the possibility of decolonial love, which she understands as "not ... just an emotion, but a practice of respect, reciprocity, consent and humility" (qtd. in Dey and Walker 2018, 2). Dionne Brand's award-winning A Map to the Door of No Return: Notes to Belonging, meanwhile, is a memoir that takes up the afterlives of slavery, longings for origins, and the impossibility of return. M. NourbeSe Philip's 2008 poetic meditation Zong!, finally, interrogates and undoes the 1781 massacre aboard the slave ship the Zong, which saw between 132 and 150 enslaved Africans thrown overboard for insurance purposes.

All of these works tangle with the embodied and bodily legacies of colonialism and imperialism, seeking new ways to deal with violence, trauma, and erasure. In the process, all challenge us to think differently about intimacy, love, violence, and desire. These texts offer us insights into toxic conditions, but also, through the metaphor of drift, into possible means of resistance.

In bringing these thinkers and writers together, we respond to the call put forward by Zainab Amadahy and Bonita Lawrence to engage in "ongoing dialogue, between Black peoples and Native people in Canada, about relationships to this land, as Indigenous peoples and those who have experienced diaspora and settlement here" (2009, 105). The alliances that 
might emerge from a conversation among these texts are not necessarily neat and tidy. As Amadahy and Lawrence observe, the relationship between Black and Indigenous peoples in this place called Canada is thorny and complex. While both communities share experiences of racialization and marginalization, they are positioned very differently within the context of the nation-state. This can result in struggles for social justice that are sometimes antithetical to one another.

Thus, while we might read each thinker through the metaphor of drift broadly speaking, their individual driftings are unique, shaped by specific histories, violences, desires, and dreams. Interrogating these many facets of drift - and allowing ourselves to drift with, through, and alongside these thinkers and their texts - allows us to respond to a question put forward by Amadahy and Lawrence at the very end of their collaborative essay: "The colonial system benefits greatly from the fact that our communities are in a perpetual state of crisis. But do we not owe it to the coming generations to find a way of supporting each other and the land that sustains us all?" (131). Drift - as a form of agency - is one decolonial gesture towards different possible futures.

As we theorize drifting, so too do we drift. Engaging with drift as methodology, we grasp at texts, our bodies and spirits searching for meaning. But the wor(l)ds do not always form; they resist, evade, refuse capture. Like leaves spiraling in a river, we float, our bodies suspended in the current, meandering through and past ideas, our thoughts swirling in the eddies along the edges of the page. So too do we tumble in the prairie wind, our thoughts gathering dust and debris into themselves as they drift through pasts and presents, into longings and desires. We drift across genre and through time and space, exploring the many faceted possibilities of drift in order to complicate maps, unmake colonial scripts, and contaminate borders.

We begin with a discussion of intimacy and desire, moving towards a central question: is it possible to make love in the face of violence? To answer this question, we turn first to Billy-Ray Belcourt and Leanne Betasamosake Simpson, both of whom consider the relationships between desire, colonial violence, and healing. In their work, drift is about excess, a too-muchness that undoes colonial fantasies. For Dionne Brand, meanwhile, desire can be read as yearning, a longing for impossible origins. Through Brand's critical interrogation of maps, drift emerges as a resistance to capture and containment but also as a process of layering and sedimentation. Taking our cue from Belcourt's "There is a Dirt Road in Me" (from This Wound is a World), Erica Violet Lee's wastelands theory (2016), Zoe S. Todd's "petrochemical politics as kin" $(2017,106)$, and Michelle Murphy's "alterlife" (2017), we then consider drift as dust, wastelands, ruin, and hope, that is, as layered and sedimented assemblages of toxic waste and opportunity. For M. NourbeSe Philip, drifting is about refusal: transforming words into sounds, cries, grief, and horror, Philip offers the endlessly haunted Middle Passage as a way of articulating the fundamental illogic of colonial logic. "There is no telling this story; it must be told" (Philip 2008,189). Finally, drift asks us to attend to ghosts, that is, to acknowledge the drift of pastpresent-future; that is, the impossibility of a future in the absence of a past.

We entrust institutions of intimacy, such as family, love, and nation, to produce the life we desire, to fulfill our optimism (Berlant 2000, 281). Intimacy, as that space of our shared breathing (Ahmed 2000, 140), facilitates relationships, bridges spaces, and mediates encounters. We are inextricably connected with one another. But, shaped through politics, bodies, and histories, intimacy is always already haunted by the very institutions that bring it into being. While colonial politics and policies have attempted to manage the boundaries of intimacy, such policies and politics are continually unsettled, undermined, and challenged. Bodies, like landscapes, evade definition: desiring and drifting, they resist the mappings laid out for them. Indeed, as the work of Antoinette Burton (1998), Durba Ghosh (2005), Cecilia Morgan 
(2008), and Ann Laura Stoler (2010), among others, suggests, if some forms of intimacy have been problematic to colonial authorities, they have also been opportunities, chances for those subject to colonial regulation to challenge colonial logics.

Desire, these scholars assert, cannot be contained by institutional logics; rather, desire is disruptive, messy, disordered, unruly. Like a heaving ocean in a storm, desire seems to drift: it spills out, spills over, breaches banks, and consumes (Simpson 2017b, 66), undermining any attempts at control. Further, like dust tumbling across a colonized landscape, drift resists containment; as vibrant matter, to follow the work of Jane Bennett (2010), it draws the human, non-human, and more-than-human into itself, in this way complicating notions of toxicity, love, survival, and thriving.

Can we make love in the face of violence (Simpson 2017 b , 43-6)? While taken up variously by the four writers and thinkers whose works we interrogate, this question lies at the heart of their thinking. How do we make sense of afterlives of colonialism and the ongoingness of violence? And further, in relation to our thinking and our drifting, what possibilities reside in reimagining, rethinking, and re-storying drift?

In his poetry collection This Wound is a World, BillyRay Belcourt refuses colonial scripts of heteronormative intimacy by embracing queer Indigenous desire as possibility, as futuristic. Flooding the boundaries between sadness and desire, violence and healing, Belcourt's poetry disrupts the implication that desire and violence are distinct, that healing comes from the separation between the two. Instead, he suggests the opposite: by blurring binaries and unmapping categories, queer Indigenous desire drifts. That is, in complicating colonial fantasies of love, nation, and family, Belcourt offers messier cosmologies of love that are borderless, violent, heartbroken, ancestral, queer, and resistant, refusing to sanitize the humanness of loving that includes grief, histories, sadness, sanctuary, and political context. As Belcourt writes in
"Love and Other Experiments," "5. what happens when decolonial love becomes a story you tell yourself after he falls asleep? / 6. i tell him, you breathe us, we are in you, look at the blood on your hands" (2017, 30; italics original). In this way, Belcourt highlights the ways in which our shared conditions of political melancholy, violence, and grief intersect with our intimate encounters with sex, desire, love, joy, comfort, and hope.

In This Wound is a World, sadness and love collude, death and sex collide, land and body entangle, fucking and healing stick. These complicated, messy relations build worlds. Belcourt's poetry holds space for the unhappy affects that often constellate love in times of suffering, grief, and fear. Instead of turning away from suffering in order to romanticize love, Belcourt asks us how desire and violence collude under conditions of colonialism (2017, 58-59). Belcourt's poetry invites the contradictions, frustrations, and complexities of queer, Indigenous love and sex, holding space for complexity as resistance.

We might consider in relation to this approach Leanne Betasamosake Simpson's personification of sadness as a lover who embodies the complicated relations we build with feeling. In "Brown Against Blue" she writes, "I cheat on myself with Sad and she never abandons me ... my constant lover Sad, as muted, dysmorphic entrapment" (2017, 35). For Simpson, this situation is not "awful"; rather, it is the messy-and necessary-kinship of love, sadness, desire, and need. Indeed, Simpson's fiction echoes Belcourt's assertion that "to be unbodied is the 'sadder than that' of love, but it is also love's first condition of possibility" (2017, 59). Love and sadness are entwined. This is what Brand would call "desire in the face of ruin" (193). To love in the face of violence, to find joy and pleasure with one another while living in oppressive conditions of erasure and oppression, is not to abandon sadness and heartache. Rather, it is to resist the notion that love and happiness are only possible through conformity to colonial ideas of family; that sadness is the singular and immobilizing affect of marginalized communities. By muddling the distinc- 
tion between "positive" and "negative" affects, decolonial love is, instead, understood as the complexity of sadness and joy, desire, and grief, unsettling colonial fantasies and institutional control of emotion and kinship. Drift, in Belcourt's framing, is necessarily about resisting containment, undoing the boundaries of colonial desire by moving across and through them.

Equally significant is the fact that Belcourt resists this violence. By flooding the pages with "unbodying," through a queered, Indigenous time and space, Belcourt protests colonial desires to police, grief, death, community, love, and intimacy through an interplay of love and sadness. In "Native Too," Belcourt juxtaposes sex and healing, writing, "i wanted him to fuck me, / so i could finally begin / to heal." $(2017,26)$. Belcourt unsettles colonial borders that have mapped intimacy and sought to control queer Indigenous desire. Belcourt's insistent drifting shows us that politics and love can never be divorced. Intimacy, here-that space between violence and desire, community and loneliness, politics and love-is the volatile glue that unites them, a haunted, keening, unbodied worlding that is constantly under negotiation. Belcourt centers queer Indigenous desire through the deconstruction of the colonial fetishization of violence and death (58). Belcourt brings fucking and political grief, desire and social melancholy, sex and healing together, drifting beyond the boundaries of sanitized intimacy as a private endeavor in service of national purity. Flooding colonial fantasies that imagine desire and violence, joy and sadness, love and hurting as distinct affects reserved for distinct bodies, Belcourt undermines racialized and gendered borders, insisting that we are always more than bodies, we are dirt roads (13), abandoned houses (27), late night text messages $(20 ; 36)$, wounds $(27)$, worlds $(12 ; 26)$.

In her study of queer Indigenous women's poetry, Arianne Burford writes that poetry can "provide a theory about how story and the erotic can destabilize colonial, heteropatriarchal power structures to envision healing from historical and present day traumas rooted in violence against Indigenous land and people" (2013, 169) The intimacy in Belcourt's writing entangles sadness, love, embodiment, violence, and desire beyond the erotic. Constellating relations of family, self, space, friends, ancestors, offspring, ghosts, and hook-ups opens new possibilities for how we might search for, find and give love as a means to survive in this world. Belcourt writes, "if i have a body, let it be a book of sad poems. i mean it," and further, "indigeneity troubles the idea of 'having' a body, so if i am somehow, miraculously, bodied then my skin is a collage of meditations on love and shattered selves" $(2017,22)$. In this way, Belcourt exercises Burford's assertion that "poetry and story can express a methodology-and thus a theory-for hope, survival, and change, spoken into existence through language. It has the power to transform, reshape, resist, and revision the world" $(2013,169)$.

But violent desire, or desire in the face of violence, is not Belcourt's only exploration of drifting intimacy. In "Native Too," Belcourt imagines love through touch, as a sort of co-worlding, a coming to being through the intimate interplay between bodies and histories: " $\mathrm{i}$ wanted to taste / a history of violence / caught in the roof of his mouth. / i wanted our saliva to mix / and create new bacterial ecologies: contagions that could infect / the trauma away" (26). Here love is infected, polluted, swollen with the trauma of colonial violence. Love spills over. Like Simpson's "Big Water," a story from her 2017 collection, This Accident of Being Lost, this love is "full, too full" (Simpson 2017b, 66). As Belcourt writes, "If I know anything now, it is that love is the clumsy name we give to a body spilling outside of itself" (2017, 59). Love-drift-here, is excess; Belcourt's love and Simpson's lake are bodies that cannot be contained, that contaminate boundaries even as they themselves are contaminated, that drift beyond themselves, spill, swell, overflow. For Simpson and Belcourt, drift-aimless, passive, and fundamentally antithetical to western imperatives to progress and efficiency-must be read as resistance. The relationships they articulate resist the contours of the western, cisgender, heteronormative, monogamous imagination and refuse the relentless forward march of "progress." 
Instead, fostered by violence and excess, they point to different possibilities for intimacy and desire in the face of colonial violence that continues to rupture relations. Relationality, for Belcourt and Simpson, emerges not through the artifices of heteronormative western monogamy but through sometimes volatile encounters.

If Belcourt and Simpson evoke drift through watery metaphors that ask us to interrogate the underpinnings of colonial assumptions of love, desire, and violence, Dionne Brand, in A Map to the Door of No Return: Notes to Belonging, returns us to land and to the endless drifting of impossible origins. This deeply personal memoir asks us to think about drift as resistance to capture. In A Map to the Door of No Return: Notes to Belonging, Dionne Brand writes an impossible map that tells a story of longing and erasure, desire, and violence. And yet this map is not just a story of loss; it is also an active unwriting and rewriting of maps and mapping. Brand's map must be understood as a fundamental rupture and an opening to a way of haunted being without origins. This new map cannot be fixed. Rather, because of the violent legacies of transatlantic slavery, it drifts. As Brand writes, "Our ancestors were bewildered because they had a sense of origins - some country, some village, some family where they belonged and from which they were rent. We, on the other hand, have no such immediate sense of belonging, only of drift" (2001, 118). Drift, in Brand's understanding, articulates the frayed edges of an impossible map (Wah 1996, 1) and the indefinability of borders (Anzaldúa 2007, 23). While linked to the forms of drift articulated by Belcourt and Simpson, in that it is founded on and through colonial histories of violence, Brand's drifting map gestures not towards what Leanne Betasamosake Simpson might understand as "land as pedagogy" (2014) but, rather, towards an unrequitable longing for a land — or lands - that she can never reclaim. In this way, this particular articulation of drift highlights the tension that lies at the heart of Indigenous and Black solidarity building: What role can land play in building alliances? If land is pedagogy, as Simpson has argued, what might that mean for peoples who have been forcibly and violently removed from their places of origin and settled in new lands, in the process displacing those who are already living there?

But at the same time, this gaping wound-this map of violence and erasure-must also be read through the lens of yearning, that is, as a desire for belonging, a haunted silence that cannot be fulfilled. If Belcourt and Simpson focus on the links between intimacy and sadness, Brand emphasizes haunting and loss. "I cannot go back to where I came from," writes Brand. "It no longer exists. It should not exist" (2001, 90). For Brand, drift is the incomprehensibility of the Middle Passage and the continuing violence in the afterlives of slavery, but this form of drift might also then be imagined through the ongoing erasure of Indigenous peoples. Drift as a process of sedimentation, for example, might be understood as the endless layering of histories across and through each other. Belcourt writes, "we are a people / who proliferate / only as potentiality" (2017, 13). Brand's map and her history too, also exist "only as potentiality," suspended in the drift both of an endless and bottomless ocean, and of yearned-for but impossible and unsettled land-based place of origin. As she observes at the very end of her memoir, "After the Door of No Return, a map was only a set of impossibilities, a set of changing locations" $(2001,224)$.

"The sea," Derek Walcott has famously written, "is history" (1979, 25). While West African spiritualities acknowledge water's life-giving essence (Stipriaan 2003; 2007), the Middle Passage is intimately associated with death. As M. Jacqui Alexander reminds us, "Not only humans made the Crossing, traveling only in one direction through Ocean given the name Atlantic. Grief traveled as well" $(2006,289)$. The haunting of the Middle Passage suggests an endlessly weeping wound of grief, what Dionne Brand articulates as "a rupture in history, a rupture in the quality of being .... a rupture of geography" $(2006,5)$.

However, Belcourt's imaginings of decolonial desire offer the possibility of hope. By making wounds into 
worlds, Belcourt subverts the pathologization of trauma, complicating wounds as more than sites to be mended. As he writes in "We Were Never Meant to Break Like This," "the future is already over, but that doesn't mean we don't have anywhere else to go" (2017, 19). Wounds that world smear past, present, and future together; they are "time travel" (Recollet 2017 , n.p.). Wounds that world are flooded with feeling and ghosts. Wounds that world are cosmic oscillations that constellate relations, times, places, feelings, bodies, and knowledge. Wounds that "stretch these star map hides so that you can build that frame and we can create maps to tomorrow" (Recollet 2017, n.p.). These constellations queer: they turn contradictions into harmonies; paradoxes are the portal to truth, blurring is a way of seeing.

"I cannot unhappen history," observes Dionne Brand (2001, 203). But what she can do, following Belcourt, is remap her desires: "A map, then," she writes, "is only a life of conversations about a forgotten list of irretrievable selves" (2001, 224). Perhaps, Brand suggests, she has placed too much hope in the impossibility of the map. Perhaps, taking her cue from Belcourt, she might instead imagine this impossible map-this drifting across time and space-as that which makes sense of the wound, the renting, the tear, the gaping. Drift keeps the wound open; it requires the "forgotten list of irretrievable selves." (Brand 2001, 224).

So, too, does drift then enable us to keep the map open, challenging its apparent fixity and undermining the possibility of easy origins. Drift is the frayed edge; the impossible resolution (Tuck \& Ree 2013). Unmappable and abject, origins as drift are mobile; not only are they unable to settle, but they refuse to settle. Indeed, as Brand writes in Land to Light On, "If I am peaceful in this discomfort, is not peace, / is getting used to harm" (1997, 3; see also Tuck \& Ree 2013, 643).

If drift has most conventionally been interrogated in relation to water, it can also be read in relation to land. Belcourt's prairie landscape drifts: dust floats and rivers meander, silt shaping snaking patterns across the plains. Belcourt writes, "there is a dirt road in me" $(2017,13)$. These words direct us to isolated prairie roads, rural routes that stretch in ribbons across plains gift-wrapped in colonial paper. While they gesture also towards Dian Million's essay “There is a River in Me: Theory from Life" (2014), Belcourt directs his attention not to rivers that sparkle and flow with life but rather to the kinds of love and relation that confound in a prairie wasteland. A dirt road, after all, doesn't appear to promise much. Drift on this road is the tumbling of leaves, weeds, dust, and wind; further, it is debris-plastic bags, beer cans, chip packages, diapers, spare tires, washing machines - all gathered together in heaps, assemblages of both waste and opportunity. In this way, we can imagine drift also as an assemblage, an accumulation of garbage dumps, clear cuts, and reserves and, further, of abandoned plantations, wastelands designed to contain the detritus of colonial administrations (see, for example, Davies 2018, Hoover 2017, Keeling \& Sandlos, 2015, Murphy 2017, Nunn 2018, Simmons 2017).

Belcourt's dirt road seems to lead nowhere; instead, it meanders towards an unsalvageable past. Drift, here, is the unfinished and seemingly impossible project of healing. While Belcourt may well want to fuck in order to heal $(2017,26)$, as a dirt road, Belcourt's body is a body denied. As Leanne Simpson writes in "road salt," "licking the road is its own humiliation" (2017, 63). A wasteland (Lee 2016), Belcourt's poetic body is "the back alley of the world" (Belcourt 2017, 25), a place frequented only by garbage trucks. Desire, shame, and disgust intermingle in an uncomfortable assemblage.

Belcourt's dirt road, the back alley of the world, Simpson's road-salted body $(2017,63)$ and over-full lake spilling its banks, tipsy with environmental contaminants (2017b, 66), Belcourt's people denied access to their languages and stalked by "massive genocidal violence .... as if death and indigeneity were co-constitutive categories" (Belcourt 2017, 58) —all, in the words of Erica Violet Lee, can be read 
as "spaces deemed unworthy of healing because of the scale and amount of devastation that has occurred there" (2016, n.p.). What does it mean to walk in the shadow of violence, to count death as your mirror? What does it mean to drift as dirt road, a back alley on the haunted loneliness of an emptied prairie?

Erica Violet Lee reminds us that while the dirt road is haunted, it is also a space of healing. "The heart of wastelands theory is simple," she writes.

Here, we understand that there is nothing and no one beyond healing. So we return again and again to the discards, gathering scraps for our bundles, and we tend to the devastation with destabilizing gentleness, carefulness, softness. For those of us in the wastelands-for those of us who are the wastelands - caring for each other in this way is refusing a definition of worthiness that will never include us. (Lee 2016, n.p.)

Wastelands theory, Lee argues, is about transformation; a theory of care made possible only through the drifting debris of a haunted past. In this framing, the dirt road, the back alley, and the road salt are sites of both refusal and resurgent love (Simpson 2017a). As Leanne Simpson writes in "Leaks," "you are rebellion, resistance, re-imagination .... you are not a vessel for white settler shame" (2013, 21; italics original). In this resistant reading, drift is not aimless, nor is it passive. Rather, as a form of refusal, drift offers resurgent love as a necessary challenge to colonial imperatives.

Indeed, for Michelle Murphy, the dirt road is defined by the very entanglement of refusal and resurgent love. Murphy uses the term "alterlife" to acknowledge that this "entanglement forms part of contemporary existence in this moment, in the ongoing aftermath. And yet the openness to alteration may also describe the potential to become something else, to defend and persist, to recompose relations to water and land" (Murphy 2017, 500). Alterlife, then, might be understood as the drift between toxicity and survival, waste and possibility, decomposition and care. For Murphy, drifting through and "bursting open categories" works as "a tactic for taking back phenomena from the epistemologies that have consistently erased the constitutive violence propping them up" (2017, 498).

This tactic extends to all our relations: Belcourt's dirt road encompasses not only the dusty wasteland of a body resisting colonialism; it also includes the plastic bags, discarded tires, and toxic garbage that drift in prairie winds, gathering in heaps along the roadside, or in haphazard dumps near reserve lands. In this way, reading through and with drift requires us to pay attention not only to desire, but also to toxicity, that is, to considering care and love in the face of wounding, violence, and contamination. We might consider here the work of Zoë S Todd, for example, who urges us to consider how care, responsibility, and relationality are complicated in a contaminated, petrochemical wasteland. We must "tend to these offspring of our petrochemical politics as kin," Todd writes $(2017,106)$. By using Indigenous relationality and Métis law as a means of "imagining how we may de-weaponise ... oil and gas" (2017, 107), Todd renegotiates oil and plastic as kin, opening new possibilities for imagining our entangled relationships. This practice, we argue, is drift; it is to love along a dirt road, to live in the hauntings of the Door of No Return, to resist. Todd's understanding of relationality reminds us that drift as practice is both about responsibility to our kin and about resistance through care. Drifting with dust, then, might be understood as an invitation to presence.

Drift, as we have already encountered, is not just about beauty, it is also about violence. So, too, is it about loss and, in this way, it must also be associated with witnessing. In her work Zong!, poet and essayist M. NourbeSe Philip reimagines the Gregson v. Gilbert court case, a case fought over insurance monies in the aftermath of a massacre that saw between 132 and 150 enslaved Africans thrown overboard from the English ship, the Zong, as a series of "Zongs" that spill across the pages of the text. In these poems, space crowds out the letters, remapping language and thought in a performance of refusal: a refusal to trade in tragedy (Austen 2011, Tuck \& Yang 2014a, 
2014b). As drift, these poems refuse the work of linearity. Instead, they are, in Philip's words, "nottelling" (2008, 198), "half-tellings" (199), and "untellings" (199) that must, nevertheless, be told. However, in its "not-telling," "half-tellings," and "untellings," Zong! is also, simultaneously, a performance of silence. In the Zongs, drift is the unsettled silence between the letters, the gaping spaces that mark the open wound of the Middle Passage. If for Brand drift might be understood as the impossibility of origins and, from there, return, for Philip, drift is the impossibility of logic; drift renders colonial language unmappable, uncomfortable, unrealizable, indeed, fundamentally illogical.

As Philip writes in "Notanda," the essay that follows the poems in Zong!:

The not-telling of this particular story is in the fragmentation and mutilation of the text, forcing the eye to track across the page in an attempt to wrest meaning from words gone astray. ... The resulting abbreviated, disjunctive, almost non-sensical style of the poems demands a corresponding effort on the part of the reader to "make sense" of an event that eludes understanding, perhaps permanently. ... In the discomfort and disturbance created by the poetic text, I am forced to make meaning from apparently disparate elements - in so doing I implicate myself. The risk-of contamination-lies in piecing together the story that cannot be told. And since we have to work to complete the events, we all become implicated in, if not contaminated by, this activity. (2008, 198)

Drift is manifest perhaps most clearly in the spaces between the letters, that is, in the unmaking of language. Words are fragmented, reduced to sounds and cries; language - as we know it-is impossible. Drifting between the sounds and cries and ululations, readers must confront the illogic of colonial logic. But Philip takes the metrics of colonial logics further. The "archival mathematics" (McKittrick 2014, 20) of the court records account for the enslaved only in numbers. However, Philip names them, arranging letters into names in a manifest-obiter dicta, or in footnotes (Philip 2008, 199) — that run along the bottom of every page of the first section of Zong!: "Zuka Tuwalole Urbi Femi Chuma Wemusa Ilesanmi Nayo Odai," she writes. "Abioye Gulai Sekelaga Dalili N'Nanna Rufaro Uwimana Nasiche Asura" (14-17). These names are a recitation, an incantation, an intimate scroll of the dead, each one called into being through and with the fragmentation of the text. They are an archival undoing- "negroes exist / for the throwing" (34) - that simultaneously challenges and brings into high relief the foundational violence of colonial and imperial endeavours. They are, in Philip's words, "the this / the that / the frenzy" $(2008,29)$.

And yet, as Erin M. Fehskens observes, Philip's list contains 228 names, far more than the reputed 132 to 150 who were massacred. Who, then, are these witnesses? What stories do they hold in their memories? "This chain of names," Fehskens offers, "bears witness to what remains unrecoverable, an historical record of Africans on board the Zong" (2012, 415). In this way, Philip forces her readers to account not only for the violence aboard the Zong but also for the violence of archival erasure (Austen 2011, Fehskens 2012, Hartman 2008, Lambert 2016, McKittrick 2014). Drift moves us between, forces us to confront illogic as we drift from sound to sound, borne on the invisible waves of Philip's literary imaginary. The story of the Zong, this drifting reminds us, should never have been realized; indeed, it cannot be realized. The Zong is an impossible story that can never be told; it makes no sense. As such it remains suspended, drifting unfinished and incomplete in its horror. Drift, here, is the impossible spacetime that somehow made events like the Zong massacre possible; it is a wounding that cannot ever be resolved, a discomfort from which we may never recover. Drift is a witnessing of ongoing horror. We may be tempted to write a happy ending, an imagined future where all of our dreams come true, but Philip's work suggests that it might be more productive to, in the words of Donna Haraway, "[stay] with the trouble" $(2016,1)$, that is, to refuse the linearity of a future orientation for a drifting that 
allows past, present, and future to collide with one another.

Also key to Philip's work is her engagement with water. Zong! undulates, rocks, bobs. Articulated visually as a series of waves, the text floats, suspended in a constantly mobile and profoundly unpredictable seascape. The saltwater of the Middle Passage. The freshwater rations that elicited the massacre. The rains that filled empty barrels. The "eleven days" of water listed in summary of the appeal (Gregson v. Gilbert 1783, 629). The bodies thrown overboard, one by one by one. As Fehskens observes:

Philip's water ... sets the literal stage of her poem-the location in question is the Atlantic_-but the poetic dispersion of the word, broken across several lines, also enacts the timely interval between the moment a body hits the water and the moment before the body's limbs are submerged. In that space of time, water breaks itself and creates a space for the body, so while the spaces in the poem communicate an increasing aquatic urgency (that salt water will become a grave and that fresh water will run out) the spaces also stand in for the bodies that disrupt the surface of the sea. (2012, 408)

This is haunted water: "Unruly, full of desire, unsettling" (Tuck \& Ree 2013, 651), this water is both surface and depth, seething with longings, grief, passions, love, and death. Here, drift offers a way in to understanding the (un)mappable as a floating, suspended haunted present not only inevitably informed and framed by the past, but at risk of being submerged, drowned, massacred by it.

"When you are a ghost," writes Belcourt in "Time Contra Time," "all time is unlived time" $(2017,40)$. Ghosts drift, formless, through the world; unsettled, they locate themselves in the between. Neither here nor there, they roam aimlessly, suspended in a netherworld from which they cannot escape. And yet, if we want to attend to ghosts, we, too, must seek to occupy the space of the in-between, the drift of pastpresent-future where meaning collapses. To unsettle intimacy; to become unbodied through love (Belcourt $2017,59)$ is to invite the cartographic ghosts in, to acknowledge their disruptive presence as integral to any mapping endeavour (Tuck \& Ree 2013, 642). We might consider, then, that to unsettle intimacy is to drift, to find meaning in the spaces that cannot be defined, whose borders are mobile, fluid, eroding. To drift is to move outside of linear time. Indeed, it is to refuse its contours altogether.

How do we account for ghosts? What do we make when linear time is flooded by histories and futures and, at the same time, all-too-much-now-ness? What do we do with wounds that refuse to be sutured? When love overwhelms armpits so porous they extrude, queering the boundary between skin and air (Belcourt 2017, 26)?

Drifting through intimacy, love, violence, and histories, Belcourt, Simpson, Brand, and Philip offer us the world-making potential of refusal (Tuck \& Yang 2014a, 2014b). Each writer, shaped by specific and individual histories of colonialism, offers us something different. Nevertheless, they share a commitment to decoloniality. "You are not a vessel for white settler shame," Leanne Simpson insists (2015, 21; italics original). Instead, she asserts a rebellious theory of love that emerges only in the spaces of the in-between, drifting on our breath, through our histories, over the water and the ice: "you are the breath over the ice on the lake. you are the one / the grandmothers sing to through the rapids. you are the / saved seeds of allies. you are the space between embraces" (2015, 21; italics original). Simpson's world-making depends on her deep connection to lands, waters, and histories: in these lines of poetry Simpson speaks to the ways that our ancestors are present through land; through our relationship with water, the past haunts us, teaches us, holds us, sings to us. The present is both a breath over frozen water, and depths that plunge to the bottom of the lake.

Brand, meanwhile, unmoored and untethered by the violent erasure of transatlantic slavery and the consequent impossibility of return, suggests that drifting 
between our haunted pasts and unknown futures is the only possible way forward. For Brand, unlike for Simpson, there is no beginning, no home to return to: "It no longer exists. It should not exist" (2001, 90). Nor is there ever an end; rather, "we are always in the middle of a journey" $(2001,49)$. And yet, as writers, thinkers, and readers, we too drift, float, and dream together, suspended between opposing poles: "There is no telling this story; it must be told" (Philip 2008, 189).

Eve Tuck and C. Ree remind us that, "for ghosts, the haunting is the resolving, it is not what needs to be resolved" (2013, 642). Drift, mobile, uncomfortable, undirected, unfinished, and ultimately impossible, can, in its myriad forms, enable us to live well with ghosts, to keep our complicated pasts alive in our presents. "These are," Karyn Recollet asserts, "the ancient future teachings on how to be in these worlds together" (2017, n.p.). In its aimlessness, drift refuses mapping, grounding, containment, capture, measurement. In its seeming passivity, drift resists colonial desires. Instead, drift celebrates new becomings, a multiplicity of possibilities, a scattering, layering, imaginative commitment to chance, potential, serendipity, and the power of the journey itself.

Acknowledgements: We thank both reviewers for their thoughtful care and attention to this essay. Their critiques and suggestions have deeply enriched and strengthened both our thinking and our writing.

\section{References}

Ahmed, Sara. 2000. Strange Encounters: Embodied Others in Post-Coloniality. London and New York: Routledge.

Alexander, M. Jacqui. 2006. Pedagogies of Crossing: Meditations on Feminism, Sexual Politics, Memory, and the Sacred. Durham: Duke University Press.

Amadahy, Zainab and Bonita Lawrence. 2009. "Indigenous Peoples and Black People in Canada: Settlers or Allies?" in Breaching the Colonial Contract: Anti-Colonialism in the US and Canada, ed. Arlo Kempf, 105-36. Dordrecht: Springer Netherlands. DOI: https://doi.org/10.1007/978-1-4020-9944-1.

Anzaldúa, Gloria. 2007. Borderlands/La Frontera: The New Mestiza. 3rd edition. San Francisco: Aunt Lute.

Austen, Veronica. 2011. "Zong!'s "Should we?": Questioning the Ethical Representation of Trauma" ESC: English Studies in Canada 37 (3-4): 61-81.

Belcourt, Billy-Ray. 2017. This Wound is a World. Calgary: Frontenac House.

Bennett, Jane. 2010. Vibrant Matter. Durham: Duke University Press.

Berlant, Lauren. 2000. "Intimacy: A Special Issue." In Intimacy, ed. Lauren Berlant, 281-288. Chicago and London: University of Chicago Press.

Brand, Dionne. 2001. A Map to the Door of No Return: Notes to Belonging. Toronto: Vintage. 1997. Land to Light On. Toronto: McClelland \& Stewart.

Burford, Arianne. 2013. "'Her Mouth is Medicine': Beth Brant and Paula Gunn Allen's Decolonizing Queer Erotics." Journal of Lesbian Studies 17 (2): $167-$ 179. 
Burton, Antoinette M. 1998. At the Heart of the Empire: Indians and the Colonial Encounter in LateVictorian Britain. Berkeley: University of California Press.

Butler, Judith. 1993. Bodies That Matter: On the Discursive Limits of "Sex". New York and London: Routledge.

Davies, Thom. 2018. "Toxic Space and Time: Slow Violence, Necropolitics, and Petrochemical Pollution," Annals of the American Association of Geographers. DOI: 10.1080/24694452.2018.147092 4.

Dey, Sayan and Jonnelle Walker. 2018. "Reviving Indigenous Spaces: Echoes of a Native Spirit. An Interview with Leanne Betasamosake Simpson.” Writers in Conversation 5 (1): 1-3.

DOI: 10.22356/wic.v5i1.26.

"drift, v.". OED Online. June 2019. Oxford University Press. https://www-oed-com.qe2aproxy.mun.ca/view/Entry/57713?rskey=HTpLJe\&res ult $=2$ (accessed June 28, 2019).

Fehskens, Erin M. 2012. "Accounts Unpaid, Accounts Untold: M. NourbeSe Philip's Zong! and the Catalogue." Callaloo 35 (2): 407-424. https://doi.org/10.1353/cal.2012.0043.

Ghosh, Durba. 2005. "Who Counts as 'Native'?: Gender, Race, and Subjectivity in Colonial India." Journal of Colonialism and Colonial History 6 (3). Accessed September 10, 2018. https://muse.jhu.edu/article/192172.

Gregson v. Gilbert. EngR 85, 99 E.R. 629. 629-630 (1783). http://www.commonlii.org/int/cases/EngR/1783/85. pdf.

Haraway, Donna. 2016. Staying with the Trouble. Durham: Duke University Press.
Hartman, Saidiya. 2008. "Venus in Two Acts." Small Axe: A Caribbean Journal of Criticism 12 (2): 1-14. DOI: $10.1215 /-12-2-1$.

Hoover, Elizabeth. 2017. The River is In Us: Fighting Toxics in a Mohawk Community. Minneapolis:

University of Minnesota Press.

Keeling, Arn and John Sandlos, eds. 2015. Mining and Communities in Northern Canada: History, Politics, and Memory. Calgary: University of Calgary Press.

Lambert, Laurie R. 2016. "Poetics of Reparation in M. NourbeSe Philip's Zong!" The Global South 10 (1): 107-129. DOI:10.2979/globalsouth.10.1.06.

Lee, Erica Violet. 2016. "In Defence of the Wastelands: A Survival Guide." GUTS 7, November 30, 2016. http://gutsmagazine.ca/wastelands/.

McKittrick, Katherine. 2014. "Mathematics Black Life," The Black Scholar: Journal of Black Studies and Research 44 (2): 16-28.

Million, Dian . 2014. "There is a River in Me: Theory from Life." In Theorizing Native Studies, edited by Audra Simpson and Andrea Smith, 31-42. Durham: Duke University Press.

Morgan, Cecilia. 2008. "Creating Interracial Intimacies: British North America, Canada, and the Transatlantic World, 1830-1914." Journal of the Canadian Historical Association. 19 (2): 76-105.

Murphy, Michelle. 2017. "Alterlife and Decolonial Chemical Relations." Cultural Anthropology 32 (2): 494-503. https://doi.org/10.14506/ca32.4.02.

Nunn, Neil. 2018. "Toxic Encounters, Settler Logics of Elimination, and the Future of a Continent." Antipode 50 (5): 1330-1348. https://doi.org/10.1111/anti.12403.

Perry, Adele. 2015. Colonial Relations: The Douglas- 
Connolly Family and the Nineteenth-Century Imperial World. Cambridge: Cambridge University Press.

Philip, M. NourbeSe. 2008. Zong! Middletown: Wesleyan University Press.

Recollet, Karyn. 2017. "Kinstillatory Gathering." C Magazine 136. https://cmagazine.com/issues/136.

Simmons, Kristen. 2017. "Settler Atmospherics." Cultural Anthropology.

https://culanth.org/fieldsights/1221-settleratmospherics.

Simpson, Leanne Betasamosake. 2017a. As We Have Always Done. Minneapolis: University of Minnesota Press.

. 2017b. This Accident of Being Lost. Toronto: House of Anansi Press. . 2013. Islands of Decolonial Love. Winnipeg: ARP Books. . 2014. "Land as Pedagogy: Nishnaabeg Intelligence and Rebellious Transformation." Decolonization: Indigeneity, Education and Society 3 (3): $1-25$.

Stipriaan, Alex van. 2003. "Watramama/MamiWata: Three Centuries of Creolization of a Water Spirit in West Africa, Suriname and Europe." Matatu - Journal for African Culture and Society 27 (1): 323-337.

. 2007. "Watramama's Transatlantic Voyage:

Legacy of the Slave Trade with Suriname." In The Transatlantic Slave Trade: Landmarks, Legacies,

Expectations, edited by James Kwesi Anquandah et al., 277-294. Accra: Sub-Saharan Publishers.

Stoler, Ann Laura. 2010. Carnal Knowledge and Imperial Power: Race and the Intimate in Colonial Rule. Oakland: University of California Press.

Todd, Zoë S. 2017. "Fish Kin and Hope: Tending to
Water Violations in amiskwaciwaskahikan and Treaty Six Territory." Afterall 43 (1): 102-107.

Tuck, Eve and C. Ree. 2013. "A Glossary of Haunting." In Handbook of Autoethnography, edited by Stacey Holman Jones, Tony E. Adams, and Carolyn Ellis, 639-58. Walnut Creek: Left Coast Press.

Tuck, Eve and K. Wayne Yang. 2014a. "R-words: Refusing Research.” In Humanizing Research: Decolonizing Qualitative Inquiry with Youth and Communities, edited by D. Paris and M. T. Winn, 223-47. Thousand Oaks: SAGE. 2014b. "Unbecoming Claims: Pedagogies of Refusal in Qualitative Research." Qualitative Inquiry 20 (6): 811-18. DOI: 10.1177/1077800414530265.

Wah, Fred. 1996. Diamond Grill. Edmonton: NeWest Press.

Walcott, Derek. 1979. The Star-Apple Kingdom. London: Farrar, Straus \& Giroux. 